\title{
ANALISIS YURIDIS KEWENANGAN KOMISI PEMBERANTASAN KORUPSI SEBAGAI PENUNTUT PELAKU TINDAK PIDANA KORUPSI
}

\author{
Yasmirah Mandasari Saragih \\ Fakultas Hukum Universitas Pembangunan Panca Budi Medan. \\ E-mail : yasmirahmandasari@yahoo.co.id \\ Teguh Prasetyo \\ Fakultas Hukum Universitas Kristen Salatiga (UKSW), Salatiga. \\ E-mail : Prof.teguh.prasetyo@gmail.com \\ Jawade Hafidz \\ Fakultas Hukum Universitas Islam Sultan Agung Semarang \\ E-mail : jawadehafidz@gmail.com
}

$\begin{aligned} \text { Sitasi : } & \text { Mandasari Saragih, Yasmirah. Teguh Prasetyo \& Jawade Hafidz. Analisis Yuridis Kewenangan Komisi } \\ & \text { Pemberantasan Korupsi (KPK) Sebagai Penuntut Pelaku Tindak Pidana Korupsi. UNIFIKASI : Jurnal IImu Hukum, } \\ & 5.1 \text { (2018), 33-44. DOI : https://doi.org/10.25134/unifikasi.v5i1.763 }\end{aligned}$

Naskah diterima : 14-12-2017 Naskah direvisi : 22-1-2018

Naskah disetujui : 10-2-2018

\begin{abstract}
Abstrak : Meningkatnya tindak pidana korupsi yang tidak terkendali akan membawa bencana tidak saja terhadap kehidupan perekonomian nasional tetapi juga terhadap kehidupan berbangsa dan bernegara pada umumnya. Pengambilalihan penyidikan dan penuntutan sebagaimana dimaksud dilakukan oleh Komisi Pemberantasan Korupsi dengan alasan laporan masyarakat mengenai tindak pidana korupsi tidak ditindaklanjuti, proses penanganan tindak pidana korupsi secara berlarut-larut atau tertunda-tunda tanpa alasan yang dapat dipertanggungjawabkan. Tujuan penelitian ini adalah untuk mengetahui dan menganalisis apa yang menjadi dasar hukum bagi kewenangan Komisi Pemberantasan Korupsi untuk melakukan penyidikan dan penuntutan? Apa kendala-kendala yang dihadapi Komisi Pemberantasan Korupsi untuk melakukan penyidikan dan penuntutan dalam tindak pidana Korupsi?. Metode penelitian yang digunakan adalah yuridis normative. Jenis data yang digunakan adalah data sekunder. Hasil penelitan yaitu Kewenangan KPK untuk menangani kasus korupsi diatur dalam Pasal 6 huruf c UU KPK bahwa KPK mempunyai tugas melakukan penyelidikan, penyidikan, dan penuntutan terhadap tindak pidana korupsi. Namun, KPK memiliki kewenangan tambahan yaitu dapat mengambil alih perkara korupsi walaupun sedang ditangani oleh Kepolisian atau Kejaksaan (Pasal 8 ayat (2) UU KPK). Akan tetapi, pengambil alihan perkara korupsi tersebut harus dengan alasan yang diatur dalam Pasal 9 UU KPK. Selain kewenangan untuk mengambil alih perkara korupsi, ada hal lain yang menjadi kewenangan KPK yaitu sebagaimana diatur dalam Pasal 11 UU KPK dan Pasal 50 UU KPK. Kesimpulan diperlukan pengaturan yang disepakati bersama untuk menghilangkan anggapan adanya tumpang tindih kewenangan dalam hal siapa yang berwenang untuk melakukan penuntutan terhadap tindak pidana korupsi muncul setelah dikeluarkannya Undang
\end{abstract}

Kata Kunci : penuntut, tindak pidana korupsi.

\section{THE ANALYSIS JURIDIS FOR AUTHORITY THE CORRUPTION ERADICATION COMMISSION AS PROSECUTOR TOWARD THE ACTORS OF CORRUPTION}

\begin{abstract}
The increasing uncontrolled corruption in general will bring disaster to the life of national economy and nation and state. The existence of a public report on corruption is not followed up, and all the consequences of the process of handling corruption in a protracted manner without a justifiable reason then the corruption eradication commission takes over the aforementioned and the demands. The purpose of this study is to know and analyze what is the basis law for the authority of the Corruption Eradication Commission to conduct investigations and prosecutions, and what are the constraints faced by the Corruption Eradication Commission to conduct investigations and prosecutions in Corruption. The research method used is juridical normative, the type of data used is secondary data. The result of research is KPK's authority to handle corruption cases regulated in Article 6 letter C of KPK Constitution, that KPK has duty to conduct investigation, investigation and prosecution of corruption crime. However, the KPK has the additional authority of being able to take over the corruption case even though it is being handled by the Police or Prosecutor's Office (Article 8 paragraph (2) of the KPK Constitution). However, the acquisition of such corruption cases must be for reasons set out in Article 9 of the KPK Constitution. In addition to that authority, there is another matter which becomes the authority of KPK that is as regulated in Article 11 and Article 50 of KPK Constitution. The conclusion is that there is a mutually agreed arrangement to dispel the assumption of overlapping authority in terms of who is authorized to prosecute corrupt acts, arising after the issuance of Constitution.
\end{abstract}

Keywords: prosecutor, corruption. 


\section{PENDAHULUAN}

Pembentukan Komisi pemberantasan Korupsi (KPK) merupakan amanat dari Pasal 43 Undang-Undang Nomor 31 Tahun 1999 tentang Pemberatasan Tindak Pidana Korupsi sebagaimana telah diubah dengan UndangUndang Nomor 20 Tahun 2001 tentang perubahan atas Undang-Undang No.31 Tahun 1999 tentang Pemberantasan Tindak Pidana Korupsi (KPK) yang independen dengan tugas dan wewenang melakukan pemberantasan tindak pidana korupsi. Komisi Pemberantasan Korupsi mempunyai Visi mewujudkan Indonesia yang bebas dari korupsi dan Misi Penggerak perubahan untuk mewujudkan bangsa yang anti korupsi.

Terkait tentang luasnya kewenangan yang dimiliki KPK dibandingkan dengan instansi Kepolisian dan Kejaksaan, ada potensi tumpang tindih dalam penggunaan wewenang antara ketiga lembaga tersebut. Seperti contoh kasus dugaan korupsi proyek simulator roda dua dan roda empat ujian surat izin mengemudi (SIM) yang melibatkan petinggi anggota kepolisian sebagai tersangka, kasus ini berujung ditariknya 20 penyidik Kepolisian di KPK yang secara tidak langsung melemahkan kinerja KPK dalam memberantas tindak pidana korupsi di Indonesia. Untuk mengatasi hal tersebut dan untuk mengefektifkan KPK dalam memberantas korupsi, perlu adanya kewenangan KPK untuk mengangkat penyidik mandiri dan sekaligus dapat mengatasi kekosongan norma di KPK.

\section{Komisi Pemberantasan Korupsi} mempunyai tugas melakukan penyelidikan, penyidikan, penuntutan terhadap tindak pidana korupsi. Pengertian penyidik adalah penyidik pada Komisi Pemberantasan Korupsi yang diangkat dan diberhentikan oleh Komisi
Pemberantasan Korupsi. Penyidik sebagaimana yang dimaksud di atas adalah menjalankan fungsi penyidikan tindak pidana korupsi. Undang-Undang Nomor 30 Tahun 2002 tentang Komisi Pemberantasan Korupsi dalam Pasal 3 dan Pasal 4 menyatakan bahwa "Komisi Pemberantasan Korupsi adalah Lembaga Negara yang dalam melaksanakan tugas dan wewenangnya bersifat independen dan bebas dari pengaruh kekuasaan umum" pada Pasal 4 "Komisi Pemberantasan Korupsi dibentuk dengan tujuan meningkatkan daya guna dan hasil guna terhadap upaya pemberantasan tindak pidana korupsi". ${ }^{1}$

Pasal 6 pada Undang-Undang Nomor 30 Tahun 2002 mengatur kewenangan KPK secara jelas, yaitu yang berbunyi sebagai berikut :

1. Koordinasi dengan instansi yang berwenang melakukan pemberantasan tindak pidana korupsi

2. Supervisi terhadap instansi yang berwenang melakukan pemberantasan tindak pidana korupsi

3. Melakukan penyidikan, penyidik dan penuntutan terhadap tindak pidana korupsi

4. Melakukan tindakan-tindakan pencegahan tindak pidana korupsi dan, Melakuakan monitor terhadap penyelenggaraan pemerintah negara.

\section{RUMUSAN MASALAH}

Sesuai dengan judul dan latar belakang masalah di atas, maka dapat dirumuskan permasalahan sebagai berikut Apa yang menjadi dasar hukum bagi kewenangan KPK untuk melakukan penyidikan dan penuntutan?

${ }^{1}$ Muhamad Yusuf, 2010, Ikhtisar Ketentuan Pencegahan dan Pemberantasan Tindak Pidana Pencucian Uang, Jakarta, NLRP, hlm 547 dan 549. 
UNIFIKASI : Jurnal IImu Hukum, Volume 05 Nomor 01, Januari 2018

Apa kendala-kendala yang dihadapi KPK untuk melakukan penyidikan dan penuntutan dalam tindak pidana Korupsi?

\section{METODE PENELITIAN}

Penelitian ini merupakan penelitian yang bersifat normatif. Jenis penelitian yang digunakan adalah yuridis normatif yaitu metode penelitian yang meneliti tentang kewenangan komisi pemberantasan korupsi (KPK) dalam upaya pemberantasan tindak pidana korupsi di Indonesia. Pendekatan penelitian yang digunakan meliputi pendekatan undang-undang, dan pendekatan kasus. Jenis data yang digunakan adalah data sekunder. Sumber data sekunder yang digunakan mencakup bahan hukum primer, bahan hukum sekunder dan bahan hukum tersier. Bahan-bahan hukum primer terdiri dari perundang-undangan, risalah dalam pembuatan perundang-undangan dan putusanputusan hakim. ${ }^{2}$

Undang-undang yang diteliti adalah UU No. 30 Tahun 2002 tentang Komisi Pemberantasan Tindak Pidana Korupsi Pemilu Pasal 50 yang berkaitan dengan kewenangan KPK dan institusi penegak hukum lainnya dalam melakukan penyidikan. Teknik pengumpulan data yang digunakan berupa bahan pustaka melalui buku-buku literatur, peraturan perundang-undangan, serta pengumpulan data, melalui media elektronik yang berhubungan dengan masalah yang diteliti. Analisis yang digunakan adalah kualitatif. yaitu menganalisis data penelitian untuk selanjutnya dikaji secara mendalam dan diinterpretasikan oleh peneliti untuk mendapatkan kesimpulan yang diharapkan. ${ }^{3}$

\footnotetext{
${ }^{2}$ Peter Mahmud Marzuki, Penelitian Hukum, Edisi Pertama,Cetakan Ke-4, Predana Media Group, Jakarta, 2008,

hlm. 141.

3 Soeryono Soekanto, Pengantar Penelitian Hukum, UI Press, Jakarta, 2001, hlm. 24.
}

p-ISSN 2354-5976, e-ISSN 2580-7382

https://journal.uniku.ac.id/index.php/unifikasi

Bahan hukum yang sudah disistematisasi kemudian dianalisis secara kualitatif.

\section{PEMBAHASAN}

\section{Dasar Hukum Bagi Kewenangan KPK Untuk Melakukan Penyidikan Dan Penuntutan}

Korupsi menurut Leden Marpaung adalah perbuatan memiliki "keuangan Negara" secara tidak sah (haram). Dalam Kamus Besar bahasa Indonesia Departemen Pendidikan dan Kebudayaan sebagaimana dikutip oleh Leden Marpaung, korupsi diartikan sebagai: "...penyelewengan atau penggelapan (uang Negara atau perusahaan dan sebagainya) untuk kepentingan pribadi atau orang lain. Kata "keuangan negara" biasanya tidak terlepas dari "aparat pemerintah", karena yang mengelola "keuangan negara" adalah aparat pemerintah. ${ }^{4}$

Pengertian Tindak Pidana Korupsi menurut Undang Undang No. 31 Tahun 1999 tentang Pemberantasan Tindak Pidana Korupsi terdapat pada Pasal 2 ayat (1) dan Pasal 3. Pasal 2 ayat (1) menentukan bahwa "setiap orang yang secara melawan hukum melakukan pebuatan memperkaya diri sendiri atau orang lain atau suatu korporasi yang dapat merugikan keuangan negara atau perekonomian Negara, dipidana penjara seumur hidup atau pidana penjara paling singkat 4 (empat) tahun dan paling lama 20 (dua puluh) tahun dan denda paling sedikit Rp. 200.000.000,00 (dua ratus juta rupiah) dan paling banyak Rp. 1.000.000.000,00 (satu milyar rupiah)". Dan dalam pasal 3 menyatakan "setiap orang yang dengan tujuan menguntungkan diri sendiri atau orang lain atau suatu korporasi, menyalahgunakan kewenangan, kesempatan atau sarana yang ada padanya karena jabatan atau kedudukan yang dapat merugikan keuangan Negara atau

${ }^{4}$ M. Lubis dan J.C. Scott, 1997, Korupsi Politik, Yayasan Obor Indonesia, Jakarta, hal. 19. 
UNIFIKASI : Jurnal IImu Hukum, Volume 05 Nomor 01, Januari 2018

perekonomian Negara, dipidana dengan pidana penjara seumur hidup atau pidana penjara paling singkat 1 (satu) tahun dan paling lama 20 (dua puluh) tahun dan atau denda paling sedikit Rp. 50.000.000,00 (lima puluh juta rupiah) dan paling banyak $\mathrm{Rp}$. 1.000.000.000,00 (satu milyar rupiah)".

Penegakan hukum terhadap tindak pidana korupsi yang dilakukan oleh institusi seperti Kejaksaan Republik Indonesia dan Kepolisian Republik Indonesia, dalam praktiknya sering menghadapi kendala dan dipandang tidak mandiri dan independen. ${ }^{5}$

Pendekatan yang dapat dilakukan terhadap masalah korupsi bermacam ragamnya, dan artinya tetap sesuai walaupun kita mendekati masalah itu, dari berbagai aspek. Pendekatan sosiologis misalnya, seperti halnya yang dilakukan oleh Syed Hussein Alatas dalam bukunya The Sociology of Corruption, akan lain artinya kalau kita melakukan pendekatan normatif; begitu pula dengan politik maupun ekonomi.

Munculnya KPK yang berfungsi melakukan penyelidikan, penyidikan dan penuntutan tindak pidana korupsi merupakan respon atas kurang efektifnya penanganan tindak pidana korupsi oleh aparat Kepolisian dan Kejaksaan. Pembentukan KPK sebagai lembaga independen yang memang mempunyai kewenangan khusus dalam upaya pemberantasan korupsi didasari akan kebutuhan adanya lembaga pemberantas korupsi yang bebas dari pengaruh kekuasaan manapun.

Undang-undang KPK secara jelas memberikan kewenangan kepada KPK yang sangat luas dan besar untuk melakukan pencegahan dan pemberantasan korupsi secara sistematik dan menjadikan KPK

5 Marwan Effendy, Kejaksaan RI Posisi dan Fungsinya dari Perspektif Hukum, Gramedia Pustaka Utama, Jakarta, $2005 \mathrm{hlm} .161$
p-ISSN 2354-5976, e-ISSN 2580-7382

https://journal.uniku.ac.id/index.php/unifikasi

sebagai tonggak utama dalam pemberantasan korupsi. Namun keberadaan KPK dengan segala tugas dan wewenangnya, memberikan celah kelemahan dengan tetap memberikan peran besar bagi Kepolisian dan Kejaksaan dalam melakukan tugas dan kewenangannya dalam pemberantasan tindak pidana korupsi.

Meningkatnya tindak pidana korupsi yang tidak terkendali akan membawa bencana tidak saja terhadap kehidupan perekonomian nasional tetapi juga terhadap kehidupan berbangsa dan bernegara pada umumnya. Tindak pidana korupsi yang meluas dan sistematis yang merupakan pelanggaran terhadap hak sosial dan hak ekonomi masyarakat. Oleh karena itu, tindak pidana korupsi tidak lagi dapat digolongkan sebagai kejahatan biasa melainkan telah menjadi suatu kejahatan luar biasa. Begitu pun dalam upaya pemberantasannya tidak lagi dapat dilakukan secara biasa, tetapi dituntut dengan cara-cara yang luar biasa. ${ }^{6}$

Penegakan hukum untuk memberantas tindak pidana korupsi yang dilakukan secara konvensional selama ini terbukti mengalami berbagai hambatan. Untuk itu diperlukan berbagai metode penegakan hukum secara luar biasa melalui pembentukan suatu badan khusus yang mempunyai kewenangan luas, independen, serta bebas dari kekuasaan mana pun dalam upaya pemberantasan tindak pidana korupsi, yang pelaksanannya dilakukan secara optimal, intensif, efektif, dan profesional. ${ }^{7}$ Oleh karena itu menurut Mertokusumo, kalau dalam penegakan hukum, yang diperhatikan hanya kepastian hukum, maka unsur-unsur lainnya dikorbankan, demikian pula kalau yang

6 Evi Hartanti, Tindak Pidana Korupsi, Edisi Kedua, Sinar Harapan Offset, Jakarta, 2008, hlm. 69.

7 Ermansjah Djaya, Memberantas Korupsi Bersama KPK kajian Yuridis Normatif UU No. 31 Tahun 1999 jo. UU No. 20 Tahun 2001 Versi UU No. 30 Tahun 2002, Cet. Pertama, Sinar Grafika Offset, Jakarta, 2008, hlm. 183 
UNIFIKASI : Jurnal IImu Hukum, Volume 05 Nomor 01, Januari 2018

diperhatikan hanyalah kemanfaatan, maka kepastian hukum dan keadilan dikorbankan. ${ }^{8}$

Pada dasarnya pembentukan KPK ditujukan untuk meningkatkan daya guna dan hasil guna terhadap upaya pemberantasan tindak pidana korupsi. KPK dapat dikategorikan sebagai badan khusus (ad hoc) yang dibentuk dengan tujuan utama melakukan penanganan terhadap kasus-kasus korupsi tertentu. Dalam Pasal 6 UndangUndang Nomor 30 Tahun 2002 tentang Komisi Pemberantasan korupsi.

KPK yang merupakan badan khusus yang mempunyai kewenangan luas, independen, serta bebas dari kekuasaan manapun untuk upaya pemberantasan korupsi. KPK dibentuk karena Kepolisian, Kejaksaan, atau lembaga-lembaga lain yang seharusnya mencegah korupsi tidak dapat berjalan dengan baik untuk memberantas korupsi di Indonesia. Cara penanganan korupsi harus dengan cara yang luar biasa. Untuk itulah dibentuk KPK yang mempunyai kewenangan luar biasa, sehingga tidak heran kalau KPK disebut sebagai lembaga super (superbody). Selanjutnya wewenang Komisi Pemberantasan Korupsi sebagaimana diamanatkan di dalam Pasal 7, 8, 9, 10, 11, 12, 13, dan 14 UndangUndang Nomor 30 Tahun 2002, sebagai pendukung pelaksanaan tugas-tugas sebagaimana dimaksud dalam Pasal 6 UndangUndang Nomor 30 Tahun 2002, Komisi Pemberantasan Korupsi.

Berdasarkan ketentuan Pasal 43 UU No. 31 Tahun 1999 tentang Pemberantasan Tindak Pidana Korupsi sebagaimana diubah dengan UU No. 20 Tahun 2001, telah dibentuk badan khusus untuk menangani upaya

8 Suwari Akhmaddhian, Penegakan Hukum Lingkungan dan Pengaruhnya Terhadap Pertumbuhan Ekonomi di Indonesia (Studi Kebakaran Hutan Tahun 2015, Jurnal Unifikasi), ISSN 2354-5976 Vol. 03 Nomor 01 Januari 2016. FH Uniku, Kuningan. pp.1-35.
p-ISSN 2354-5976, e-ISSN 2580-7382

https://journal.uniku.ac.id/index.php/unifikasi

pemberantasan korupsi. Badan khusus tersebut dalam UU No. 30 Tahun 2002 adalah Komisi Pemberantasan Tindak Pidana Korupsi yang selanjutnya disebut Komisi Pemberantasan Korupsi (KPK). Pembentukan KPK didasarkan pada kebutuhan untuk mendapatkan jaksa penuntut umum (JPU) yang independen dalam menangani kasuskasus korupsi ${ }^{9}$

Pemberantasan Korupsi kini sudah menjadi agenda masyarakat Internasional sekaligus juga telah disepakati ketentuanketentuan yang mengatur tentang pembentukan suatu lembaga anti korupsi yang independen, mekanisme pengembalian asset hasil korupsi di Negara lain melalui "mutual legal assistance"; ekstradisi, "joint investigation; transfer of sentenced person; transfer of proceedings; dan kewajiban pelaporan tahunan kepada "lembaga internasional" yang disebut "Conference of the Parties". 10

Penegakan hukum atau penerapan hukum dan proses peradilan atau proses di pengadilan merupakan unsur penting kepastian hukum. Tetapi dua hal di atas belum memadai untuk mencapai kepastian hukum, apalagi menjamin pemenuhan kebutuhan dan pemuasan kepentingan hukum pencari keadilan atau masyarakat luas pada umumnya. ${ }^{11}$

Keberadaan KPK sangat dibutuhkan mengingat sifat dan akibat korupsi yang begitu besar, menggerogoti kekayaan Negara dan sumber ekonomi rakyat, sehingga dapat

9 M. Syamsudin, Faktor-Faktor Sosiolegal yang Menentukan dalam Penanganan Perkara Korupsi di Pengadilan, Jurnal Hukum, Vol. 17 No.3 Juli 2010, Yogyakarta, hlm. 416

10 Romli Atmasasmita, 2004, Sekitar Masalah Korupsi Aspek Nasional dan Aspek Internasional, Mandar Maju, Bandung, hal. 26.

${ }^{11}$ Bagir manan, Sistem Peradilan Berwibawa (Suatu Pencarian), Cet. Pertama, FH UII Press, Yogyakarta, 2005, hlm. 72. 
UNIFIKASI : Jurnal IImu Hukum, Volume 05 Nomor 01, Januari 2018

dipandang sebagai pelanggaran HAM, yakni hak-hak sosial ekonomi rakyat. Oleh karenanya masyarakat mendambakan KPK sebagai lembaga yang menjadi harapan bangsa Indonesia yang muncul di tengahtengah lembaga penegakan hukum yang ada seiring dengan krisis kepercayaan masyarakat terhadap hukum itu sendiri.

Kewenangan lain yang lebih luas dari KPK adalah mengambil alih wewenang penyidikan dan penuntutan dari pihak kepolisian dan kejaksaan dengan prinsip "trigger mechanism" dan "take over mechanism". Pengambilalihan wewenang ini dapat dilakukan jika terdapat indikasi "unwiliingness" dari institusi terkait dalam menjalankan tugas dan wewenangnya. Indikasi adanya "unwiliingness" tersebut berdasarkan Pasal 9 UU KPK, yaitu (i) adanya laporan masyarakat menganai tindak pidana korupsi yang tidak ditindak lanjuti, (ii) proses penanganan tindak pidana korupsi yang berlarut-larut, (iii) adanya unsur nepotisme yang melindungi pelaku korupsi, (iv) adanya campur tangan pihak eksekutif, legislatif dan yudisial, (v) alasan-alasan lain yang menyebabkan penanganan tindak pidana korupsi sulit dilaksanakan.

Dampak dari tindak pidana korupsi dapat dilihat dari terjadinya berbagai bencana alam dan kerusakan lingkungan seperti banjir, bahkan Nyoman Serikat Putra Jaya mengatakan bahwa akibat negatif dari adanya tindak pidana korupsi sangat merusak tatanan kehidupan bangsa, bahkan korupsi merupakan perampasan hak ekonomi dan hak sosial masyarakat Indonesia. ${ }^{12}$

Korban korupsi memang tidak kasat mata dan bukan individu, tetapi Negara, justru karena invisibility inilah maka public

12 Nyoman Sarekat Putra Jaya. 2008. Beberapa Pemikiran ke arah Pengembangan Hukum Pidana. Citra Aditya Bakti. HIm. 69.
p-ISSN 2354-5976, e-ISSN 2580-7382

https://journal.uniku.ac.id/index.php/unifikasi

kebanyakan tidak merasakan bahwa korupsi merupakan tindak pidana yang membahayakan warga (setidaknya secara langsung). Lain halnya dengan tindak pidana jalanan jauh lebih tinggi dibanding dengan tindak pidana korupsi, demikian persepsi masyarakat yang sulit untuk diubah karena kasat matanya tindak pidana jalanan. ${ }^{13}$ Tindak Pidana Korupsi merupakan kejahatan luar biasa sehingga perlu penanganan yang kompresehensif karena terjadi kesulitan-kesuliatan salah satunya adalah dalam hal penuntutan. ${ }^{14}$

Segala kewenangan yang berkaitan dengan penyelidikan, penyidikan, dan penuntutan yang diatur dalam Undang-Undang Nomor 8 Tahun1981 tentang Hukum Acara Pidana berlaku juga bagi penyelidik, penyidik, dan penuntut umum pada Komisi Pemberantasan Korupsi. Ketentuan sebagaimana dimaksud dalam Pasal 7 ayat (2) Undang-Undang Nomor 8 Tahun 1981 tentang Hukum Acara Pidana tidak berlaku bagi penyidik tindak pidana korupsi sebagaimana ditentukan dalam Undang-Undang ini. (Pasal 38 UU Nomor 30 Tahun 2002 tentang Komisi Pemberantasan Tindak Pidana Korupsi (UU 30/2002)).

Sistem peradilan peradilan pada hakeketnya identik dengan sistem penegakan hukum, karena proses peradilan pada hakekatnya suatu proses menegakkan hukum, jadi hakekatnya identik dengan "sistem kekuasaan kehakiman" karena "kekuasaan kehakiman" pada dasarnya merupakan "kekuasaan/kewenangan menegakkan hukum". Apabila difokuskan dalam bidang hukum

13 Harkrisnowo, Harkristuti. 2009. Korupsi, Konspirasi dan Keadilan di Indonesia, dalam jurnal kajian putusan pengadilan DICTUM, L e I P 1. HIm. 67.

${ }^{14}$ Laurance Hasiholan Pasaribu, Iman Jauhari, Elvi Zahara. Kajian Yuridis Terhadap Putusan Bebas Tindak Pidana Korupsi (Studi Kasus Pada Pengadilan Negeri Medan), Jurnal Mercatoria, Vol.1 No.2 Tahun 2008. HIm.130-140. 
UNIFIKASI : Jurnal IImu Hukum, Volume 05 Nomor 01, Januari 2018

pidana, dapatlah dikatakan bahwa "sistem Peradilan Pidana" (dikenal dengan istilah SPP atau Criminal Justice System/CJS) pada hakekatnya merupakan "Sistem Peradilan Pidana" yang pada hakekatnya juga identik dengan "Sistem Kekuasaan Kehakiman di bidang Hukum Pidana" (SKK-HP). ${ }^{15}$

Penyidikan, penuntutan, dan pemeriksaan di sidang pengadilan serta pelaksanaan putusan yang telah memperoleh kekuatan hukum tetap terhadap tindak pidana sebagaimana dimaksud dalam UndangUndang ini dilakukan sesuai dengan ketentuan peraturan perundang-undangan, kecuali ditentukan lain dalam Undang-Undang ini (Pasal 68 UU 8/2010).

Penyidikan tindak pidana korupsi dilakukan oleh penyidik tindak pidana asal sesuai dengan ketentuan hukum acara dan ketentuan peraturan perundang-undangan, kecuali ditentukan lain menurut UndangUndang ini. (Pasal 74 UU 8/2010) Besarnya intervensi yang ditujukan pada KPK menjadi tantangan tersendiri bagi komisioner KPK dalam menjalankan tugas dan Kewenangannya. Terkait dengan kewenangan KPK tersebut dalam hal kebijakan mencegah dan memberantas tindak pidana korupsi, akan terbatas pada beberapa hal saja.

Ketentuan tersebut dapat dilihat pada pasal 11 Undang-undang Nomor 30 tahun 2002 tentang Komisi pemberantasan tindak pidana korupsi, menyatakan bahwa tindak pidana korupsi yang masuk dalam kewenangan KPK adalah:

a. Melibatkan aparat penegak hukum, penyelenggara negara, dan orang lain yang ada kaitannya dengan tindak pidana korupsi yang dilakukan oleh

${ }^{15}$ Muladi. 1995. Kapita Selekta Sistem Peradilan Pidana, Badan Penerbit Universitas Diponegoro. Semarang. HIm. 20.
p-ISSN 2354-5976, e-ISSN 2580-7382

https://journal.uniku.ac.id/index.php/unifikasi

aparat penegak hukum atau penyelenggara negara;

b. Mendapatkan perhatian yang meresahkan masyarakat; dan/atau

c. Menyangkut kerugian negara paling sedikit Rp.1.000.000.000,00 (satu miliar rupiah).

Dengan ini KPK dihadirkan hanya menangani kasus korupsi yang memenuhi kriteria tersebut sehingga kewenangannya pun terbatas. Walaupun pada pasal lain di tentukan bahwa KPK dapat mengambil alih perkara yang ditangani aparat penegak hukum lainnya dengan beberapa alasan, salah adalah dengan alasan penanganan tindak pidana korupsi mengandung unsur korupsi.

Pada masa rezim orde baru berkuasa mekanisme kerja lembaga penegak hukum konvensional tersebut tidak lepas dari control eksekutif dan pada masa transisi ini eksistensi lembaga konvensional penegak hukum tersebut mengalami krisis legitimasi. ${ }^{16}$

Pembatasan seperti ini secara langsung mempersempit dan mengurangi porsi kewenangan KPK sebagai komisi yang dibentuk khusus memberantas korupsi, meskipun dalam hal tertentu KPK bisa saja mengesampingkan beberapa ketentuan tersebut. Namun hal ini tetap saja menjadi kendala tersendiri bagi KPK dalam menjalankan tugas dan kewenangannya. Misalnya adanya kewenangan Kejaksaan dan KPK dalam halb melakukan penuntutan terhadap tindak pidana korupsi, maka telah terjadi dualisme penuntutan terhadap tindak pidana korupsi. padahal dalam ketentuan undang-undang yang memiliki kewenangan untuk melakukan penuntutan terhadap tindak pidana adalah jaksa di lingkungan Kejaksaan Republik Indonesia,

16 George Junus Aditjondro. 2002. Korupsi Kepresidenan di Masa Orde Baru, dalam Mencari Uang Rakyat 16 Kajian Korupsi di Indonesia. Buku I. Yayasan Aksara. Yogyakarta. HIm. 35. 
UNIFIKASI : Jurnal IImu Hukum, Volume 05 Nomor 01, Januari 2018

akan tetapi secara khusus terhadap tindak pidana korupsi.

Apabila dikaitkan dengan pendapat Lawrence Friedman10 tentang sistem hukum yang terdiri dari subsansi, struktur dan kultur hukum maka penegakan hukum pidana adalah merupakan upaya untuk membuat substansi hukum, struktur hukum dan budaya hukum pidana dapat terwujud secara konkret. Penegakan hukum tindak pidana korupsi dapat diartikan pula sebagai konkritisasi terhadap sistem hukum yang berkaitan dengan tindak pidana korupsi yaitu usaha untuk mewujudkan substansi hukum, struktur hukum dan budaya hukum yang berkaitan dengan pemberantasan tindak pidana korupsi secara konkret. ${ }^{17}$

KPK juga diberi wewenang untuk melakukan penuntutan. Hal itu tentunya member kesan negatif terkait tidak adanya jaminan kepastian hukum, yang pada akhirnya membuat masyarakat bingung dan tidak percaya lagi kepada hukum dan aparat penegak hukum.

Dalam melaksanakan tugas penyelidikan, penyidikan, dan penuntutan sebagaimana dimaksud dalam Pasal 6 huruf $c$, Komisi Pemberantasan Korupsi berwenang:

1) Melakukan penyadapan dan merekam pembicaraan;

2) Memerintahkan kepada instansi yang terkait untuk melarang seseorang bepergian ke luar negeri;

3) Meminta keterangan kepada bank atau lembaga keuangan lainnya tentang keadaan keuangan tersangka atau terdakwa yang sedang diperiksa;

4) Memerintahkan kepada bank atau lembaga keuangan lainnya untuk memblokir rekening yang diduga hasil

17 Satjipto Rahardjo. Masalah Penegakan Hukum: Suatu Tinjauan Sosiologis. Badan Pembinaan Hukum Nasional Departemen Kehakiman. Jakarta. HIm. 56.
p-ISSN 2354-5976, e-ISSN 2580-7382

https://journal.uniku.ac.id/index.php/unifikasi

dari korupsi milik tersangka, terdakwa, atau pihak lain yang terkait;

5) Memerintahkan kepada pimpinan atau atasan tersangka untuk memberhentikan sementara tersangka dari jabatannya;

6) Meminta data kekayaan dan data perpajakan tersangka atau terdakwa kepada instansi yang terkait:

7) Menghentikan sementara suatu transaksi keuangan, transaksi perdagangan, dan perjanjian lainnya atau pencabutan sementara perizinan, lisensi serta konsesi yang dilakukan atau dimiliki oleh tersangka atau terdakwa yang diduga berdasarkan bukti awal yang cukup ada hubungannya dengan tindak pidana korupsi yang sedang diperiksa;

8) Meminta bantuan Interpol Indonesia atau instansi penegak hukum negara lain untuk melakukan pencarian, penangkapan, dan penyitaan barang bukti di luar negeri;

9) Meminta bantuan kepolisian atau instansi lain yang terkait untuk melakukan penangkapan, penahanan, penggeledahan, dan penyitaan dalam perkara tindak pidana korupsi yang sedang ditangani. (Pasal 12 UU 30/2002)

Adapun pengertian jaksa menurut Pasal 1 angka1 Undang-Undang Nomor 16 Tahun 2004 tentang Kejaksaan RI menyebutkan bahwa jaksa adalah pejabat fungsional yang diberi wewenang oleh undang-undang untuk bertindak sebagai penuntut umum dan pelaksana putusan pengadilan yang telah memperoleh kekuatan hukum tetap serta wewenang lain berdasarkan undang-undang. Lebih lanjut dijelaskan mengenai jabatan fungsional jaksa dalam angka 4 adalah jabatan yang bersifat keahlian teknis dalam organisasi Kejaksaan yang karena fungsinya memungkinkan kelancaran pelaksanaan tugas Kejaksaan. KUHAP tidak memberikan 
UNIFIKASI : Jurnal IImu Hukum, Volume 05 Nomor 01, Januari 2018

pengertian tentang jaksa, jadi dapat disimpulkan bahwa yang dimaksud dengan jaksa dalam KUHAP adalah apa yang disebutkan dalam Undang-Undang Kejaksaan RI, di mana jaksa yang dimaksud berada dalam lingkup organisasi Kejaksaan.

Bahwa selanjutnya terjadi tumpang tindih konsepsi yang berhubungan dengan tugas dan kewenangan Kejaksaan disebabkan karena beberapa faktor yaitu:

a) Sistem peradilan pidana terpadu yang dianut dalam KUHAP menimbulkan permasalahan sehubungan dengan kewenangan penuntutan Kejaksaan dan sub-sistem penegakan hukum lainnya yaitu Kepolisian dalam hal penyidikan dan Pengadilan dalam proses peradilan.

b) Kedudukan Kejaksaan dalam konteks hukum nasional berdasarkan UndangUndang No. 16 Tahun 2004 tentang Kejaksaan RI menempatkan lembaga ini berada di lingkungan eksekutif yang menyebabkan Kejaksaan tidak mandiri dan independen.

c) Pengurangan dan pembatasan kewenangan oleh Undang-Undang, baik di bidang penyidikan maupun dalam bidang penuntutan. Hal ini dapat dilihat dengan terbentuknya Komisi Pemberantasan Tindak Pidana Korupsi berdasarkan Keppres No 266/M/2003 sebagai tindak lanjut Undang-Undang No. 30 Tahun 2002 tentang Komisi Pemberantasan Korupsi.

Selain Kejaksaan, ternyata KPK juga memiliki kewenangan untuk melakukan penuntutan terhadap tindak pidana korupsi. Hal tersebut dapat dilihat dalam rumusan Pasal 6 huruf c Undang-Undang Nomor 30 Tahun 2002 tentang Komisi Pemberantasan Tindak PidanaKorupsi, yaitu KPK mempunyai tugas melakukan tindakan penyelidikan, penyidikan, dan penuntutan terhadap tindak
p-ISSN 2354-5976, e-ISSN 2580-7382

https://journal.uniku.ac.id/index.php/unifikasi

pidana korupsi. Rumusan pasal ini jelas bahwa KPK juga berwenang melakukan tindakan penuntutan terhadap tindak pidana korupsi.

Namun, UU KPK tersebut memberikan kualifikasi terhadap tindak pidana korupsi mana saja yang dapat ditangani oleh KPK. Sebagaimana yang ditegaskan dalam Pasal 11 UU KPK bahwa dalam melaksanakan tugasnya, KPK berwenang untuk melakukan penuntutan terhadap tindak pidana korupsi: Yang melibatkan aparat penegak hukum, penyelenggara negara, dan orang lain yang ada kaitannya dengan tindak pidana korupsi yang dilakukan oleh aparat penegak hukum atau penyelenggara negara; Mendapatkan perhatian yang meresahkan masyarakat: Menyangkut kerugian negara paling sedikit satu miliar rupiah.

Kualifikasi tersebut mengandung arti bahwa apabila suatu tindak pidana korupsi masuk dalam rumusan dari pasal tersebut, maka KPK yang berwenang untuk melakukan tindakan penuntutan. Namun, dalam beberapa kasus korupsi di Indonesia yang nilai kerugian negara ditafsirkan di atas satu milyar rupiah serta melibatkan penyelenggara negara dalam hal ini pemerintah (sesuai dengan kualifikasi pasal $11 \mathrm{KPK}$ ), penuntutan terhadap perkara korupsi tersebut malah ditangani oleh Kejaksaan, bukan KPK. Contohnya, kasus yang melibatkan Elly Lasut, Bupati Kepulauan Talaud Sulawesi Utara, dalam kasus Surat Perintah Perjalanan Dinas (SPPD) fiktif senilai 7,7 milyar rupiah serta kasus Gerakan Daerah Orang Tua Asuh (GDOTA) senilai 1,5 milyar rupiah. Perkara korupsi yang melibatkan penyelenggara negara tersebut tindakan penuntutannya dilakukan oleh Kejaksaan bukan oleh KPK. Hal seperti ini menimbulkan suatu ketidakjelasan dan ketidakpastian hukum dalam hal siapa sebenarnya yang berwenang untuk melakukan penuntutan terhadap tindak pidana korupsi. 
UNIFIKASI : Jurnal IImu Hukum, Volume 05 Nomor 01, Januari 2018

Berdasarkan contoh kasus tersebut seharusnya ada pemisahan yang jelas antara tugas dan wewenang KPK dan Kejaksaan dalam menangani tindak pidana korupsi, secara khusus dalam hal penuntutan. Jangan sampai terkesan bahwa lembaga satu mengambil alih kewenangan lembaga lainnya. Hal tersebut dimaksudkan agar adanya penjernihan fungsi yang bertujuan untuk menghilangkan kekacauan dan tumpang tindih fungsi dan wewenang penuntutan. Selain itu dengan adanya spesifikasi yang jelas dalam wewenang untuk melakukan penuntutan akan lebih memberikan dan menjamin terwujudnya suatu kepastian hukum, sehingga hasil yang didapatkan akan lebih efektif dan maksimal.

Kewenangan KPK untuk melakukan penuntutan terhadap tindak pidana korupsi lebih diperluas lagi dengan wewenang untuk mengambil alih penuntutan terhadap tindak pidana korupsi.

Kendala-Kendala Yang Dihadapi KPK Untuk Melakukan Penyidikan Dan Penuntutan Dalam Tindak Pidana Korupsi

Di satu pihak, fungsi KPK, sebagai lembaga Super Body institusi penegak hukum kejahatan korupsi telah mendapatkan pembenaran juridis. Sehingga kehadiran KPK, umumnya cenderung menimbulkan kontorversial dalam praktek penegakan hukum kejahatan korupsi di tingkat lapangan. Terutama, adanya kesan tebang pilih yang tidak dapat dihilangkan jejaknya. Di pihak lain, peran institusi penegak hukum, seperti kepolisian, kejaksaan merasa terkurangi.

Sebab, dahulu penanganan kasus korupsi merupakan kewenangan bersama polisi, jaksa. Akan tetapi, sejak keluarnya Undang-Undang No.30/2002, kejahatan korupsi, dalam ukuran tertentu (di atas 1 miliar) merupakan jurisdiksi kompetensi KPK. Sehingga, pihak kepolisian, yang merupakan
p-ISSN 2354-5976, e-ISSN 2580-7382

https://journal.uniku.ac.id/index.php/unifikasi

pintu gerbang proses penyelidikan dan penyidikan dalam penegakan hukum dalam tindak pelanggaran dan kejahatan, termasuk kejahatan korupsi menjadi amat terkurangi. Dalam kejahatan korupsi tertentu, polisi tidak dapat melakukan penyelidikan dan penyidikan di tingkat lapangan, menempatkan situasi kontra-produktif bagi citra kepolisian.

Problematika dalam penegakan hukum tindak pidana korupsi ini harus diselesaikan dengan baik, maka perlu harmonisasi antar lembaga penanganan tindak pidana korupsi, artinya lembaga penanganan korupsi mengetahui tugas dan wewenang masingmasing dalam memberantas dan menegakkan hukum tindak pidana korupsi. Yang paling penting dalam penegakan hukum tindak pidana korupsi ini adalah kerjasama antar lembaga penanganan tindak pidana korupsi dengan memberikan penanganan penyelidikan maupun penyidikan bahkan bisa sharing dalam menangani kasus korupsi.

\section{SIMPULAN}

Kewenangan KPK untuk menangani kasus korupsi diatur dalam Pasal 6 huruf c UU No. 30 Tahun 2002 tentang Komisi Pemberantasan Korupsi bahwa KPK mempunyai tugas melakukan penyelidikan, penyidikan, dan penuntutan terhadap tindak pidana korupsi. Namun, KPK memiliki kewenangan tambahan yaitu dapat mengambil alih perkara korupsi walaupun sedang ditangani oleh Kepolisian atau Kejaksaan (Pasal 8 ayat (2) UU KPK). Akan tetapi, pengambil alihan perkara korupsi tersebut harus dengan alasan yang diatur dalam Pasal 9 UU KPK. Selain kewenangan untuk mengambil alih perkara korupsi, ada hal lain yang menjadi kewenangan KPK yaitu sebagaimana diatur dalam Pasal 11 UU KPK dan Pasal 50 UU KPK. 
UNIFIKASI : Jurnal IImu Hukum, Volume 05 Nomor 01, Januari 2018

SARAN

Diperlukan pengaturan yang disepakati bersama untuk menghilangkan anggapan adanya tumpang tindih kewenangan dalam hal siapa yang berwenang untuk melakukan penuntutan terhadap tindak pidana korupsi muncul setelah dikeluarkannya UndangUndang Nomor 31 Tahun 1999 tentang Pemberantasan Tindak Pidana Korupsi kendatipun Pasal 26 undang-undang ini menyebutkan bahwa penyidikan, penuntutan, dan pemeriksaan di sidang Pengadilan terhadap tindak pidana korupsi, dilakukan berdasarkan hukum acara pidana yang berlaku, kecuali ditentukan lain oleh undangundang ini begitu juga rumusan Pasal 39 Undang-Undang Nomor 30 Tahun 2002 tentang Komisi Pemberantasan Tindak Pidana Korupsi yang menyebutkan bahwa penyelidikan, penyidikan, dan penuntutan tindak pidana korupsi dilakukan berdasarkan hukum acara pidana yang berlaku dan berdasarkan Undang-Undang Nomor 31 Tahun 1999 yang telah diubah menjadi Undang-Undang Nomor 20 Tahun 2001 tentang Pemberantasan Tindak Pidana Korupsi namun tetap saja tumpang tindi kewenangan tetap muncul di institusi yang besar ini.

\section{DAFTAR PUSTAKA}

Aditjondro, George Junus. 2002. Korupsi Kepresidenan di Masa Orde Baru, dalam Mencari Uang Rakyat 16 Kajian Korupsi di Indonesia. Buku I. Yogyakarta: Yayasan Aksara.

Akhmaddhian, Suwari. Penegakan Hukum Lingkungan dan Pengaruhnya Terhadap Pertumbuhan Ekonomi di Indonesia (Studi Kebakaran Hutan Tahun 2015, Jurnal Unifikasi, ISSN 2354-5976 Vol. 03 Nomor 01 Januari 2016. FH Uniku, Kuningan. pp.1-35.
p-ISSN 2354-5976, e-ISSN 2580-7382

https://journal.uniku.ac.id/index.php/unifikasi

Atmasasmita, Romli. 2004. Sekitar Masalah Korupsi Aspek Nasional dan Aspek Internasional. Bandung : Mandar Maju.

Atmasasmita, Romli. 2004. Sekitar Masalah Korupsi Aspek Nasional dan Aspek Internasional. Bandung : Mandar Maju.

Djaya, Ermansjah. 2008. Memberantas Korupsi Bersama KPK kajian Yuridis Normatif UU No. 31 Tahun 1999 jo. UU No. 20 Tahun 2001 Versi UU No. 30 Tahun 2002, Cet. Pertama. Jakarta : Sinar Grafika Offset.

Effendy, Marwan. 2005. Kejaksaan RI Posisi dan Fungsinya dari Perspektif Hukum, Jakarta : Gramedia Pustaka Utama.

Hartanti, Evi. 2008. Tindak Pidana Korupsi, Edisi Kedua. Jakarta : Sinar Harapan Offset.

Harkrisnowo. Harkristuti. 2009. Korupsi, Konspirasi dan Keadilan di Indonesia, dalam jurnal kajian putusan pengadilan DICTUM, L e I P 1.

Ibrahim, Jhonny. 2005. Teori dan Metode Penelitan Hukum Normatif. Malang : Bayumedia Publishing.

Jaya, Nyoman Sarekat Putra. 2008. Beberapa Pemikiran ke arah Pengembangan Hukum Pidana. Jakarta : Citra Aditya Bakti.

Lubis, M. dan J.C. Scott. 1997. Korupsi Politik, Jakarta : Yayasan Obor Indonesia.

Manan, Bagir. 2005. Sistem Peradilan Berwibawa (Suatu Pencarian), Cet. Pertama. Yogyakarta: FHUII Press.

Marzuki, Peter Mahmud. 2008. Penelitian Hukum. Edisi Pertama,Cetakan Ke-4. Jakarta : Predana Media Group.

Muladi. 1995. Kapita Selekta Sistem Peradilan Pidana, Semarang : Badan Penerbit Universitas Diponegoro. 
UNIFIKASI : Jurnal IImu Hukum,

Volume 05 Nomor 01, Januari 2018
p-ISSN 2354-5976, e-ISSN 2580-7382

https://journal.uniku.ac.id/index.php/unifikasi

Pasaribu, Laurance Hasiholan, Iman Jauhari,

Elvi Zahara. Kajian Yuridis Terhadap

Putusan Bebas Tindak Pidana Korupsi

(Studi Kasus Pada Pengadilan Negeri

Medan), Jurnal Mercatoria. Vol.1

No.2 Tahun 2008. HIm. 130-140.

Rahardjo, Satjipto. Masalah Penegakan Hukum: Suatu Tinjauan Sosiologis.

Badan Pembinaan Hukum Nasional Departemen Kehakiman. Jakarta.

Rahardjo, Soeryono. 2006. Pengantar Penelitian Hukum, Jakarta: UI Press.

Syamsudin, M. Faktor-Faktor Sosiolegal yang Menentukan dalam Penanganan Perkara Korupsi di Pengadilan. Jurnal Hukum. Vol. 17 No.3 Juli 2010. Yogyakarta.

Yusuf, Muhamad. 2010. Ikhtisar Ketentuan

Pencegahan dan Pemberantasan

Tindak Pidana Pencucian Uang, Jakarta : NLRP

Undang-Undang No. 8 Tahun 1981 tentang Kitab Undang-Undang Hukum Acara Pidana.

Undang-Undang No. 31 Tahun 1999 tentang Pemberantasan Tindak Pidana Korupsi. 